\title{
Allelopathic Control Effect of Complex Formulation of Compound Microbial Community and Bio-Organic Fertilizer on Cucumber fusarium Wilt
}

\author{
LIJIN QIN ${ }^{1 *}$, ZENGMING ZHONG ${ }^{2}$, DANDAN WANG ${ }^{1}$, HAIQI HU ${ }^{1}$, DUO LI ${ }^{1}$, \\ YINBIAO GAO ${ }^{1}$, SHOUZHENG WANG ${ }^{1}$ \\ ${ }^{1}$ Chifeng University, Chifeng 024000, China \\ ${ }^{2}$ Beijing Qigao Biologics Co., Ltd., Beijing 100193, China
}

\begin{abstract}
To study the influence of complex formulation of "WoFengKang" compound microbial community and bio-organic fertilizer on allelopathic effect of cucumber fusarium wilt and field growth traits, in this experiment, different indoor treatments were taken to cultivate cucumber fusarium wilt using soil leaching liquor and Cucumis sativus growth index, fusarium wilt disease index were determined, so that allelopathic control effect of different dosages of compound microbial community on cucumber fusarium wilt can be investigated. The results showed that: compared with conventional $C K$, cucumber fusarium wilt cultured in different soil leaching liquor had smaller diameter. Where, colony diameter in treatment 3 was the smallest, which was $36.72 \mathrm{~mm}$. Compound microbial community had certain allelopathic effect on cucumber fusarium wilt, and inhibition effect was shown with allelopathic effect reaching 27.13 43.91\%. The above differently-treated soil was loaded to seedling-raising pot for Cucumis sativus planting. Cucumber fusarium wilt (FOC) was inoculated in the rough leaf stage of Cucumis sativus, thus reducing the disease index of cucumber fusarium wilt with obvious control effect reaching 55.94 72.63\%. Where, treatment 3 demonstrated the best effect and allelopathic control effect reached $72.63 \%$ after $15 d$ inoculation. The complex formulation of the two promoted vegetative growth of Cucumis sativus, lowered node of the first female flower bud, increased the number of female flowers within 30 nodes, so that $3.25 d$ early flowering and $4.75 d$ delayed seedling raising were achieved. Therefore, application of microbial community amid and after Cucumis sativus field planting has certain allelopathic control effect on cucumber fusarium wilt, which can effectively reduce the incidence of cucumber fusarium wilt and provide a scientific basis for the allelopathic prevention and control of soil-borne diseases in Cucumis sativus.
\end{abstract}

Keywords: compound microbial community; cucumber fusarium wilt; soil leaching liquor; allelopathic effect; prevention and control effect

\section{Introduction}

Cucumber fusarium wilt, a soil-borne disease with serious hazard in Cucumber production and cultivation, is difficult to control. So far, there has been no effective control method yet. At present, chemical pesticides are mainly used for its prevention and control in production of Cucumber. However, the control effect is poor and environmental pollution and pesticide residues are easy occurrences $[1,2]$. Compound microbial community is one or several kinds of beneficial fungus that can move freely in the soil or serve as epiphyte in the plant rhizosphere, root surface, stems and leaves, etc., which can promote plant growth. Allelopathic effect means favorable or unfavorable effect of metabolic secretions of plant (or including microorganisms) on other plants (including microorganisms) in the environment [1-15].

Understanding allelopathic effects of different plants and using this allelopathic promotion or inhibition between plants (including microorganisms) to control soil-borne diseases of plant is a prominent problem waiting urgent solution in today's "scale" and "simplified" planting production.

\footnotetext{
*email: lijin.q612@gmail.com
} 
Studies have confirmed that compound microbial community can inhibit the reproduction of pathogenic microorganisms and effectively prevent and control the occurrence of plant diseases. Yang et al. [16], measured the spores and hyphae of Botrytis cinerea using flat plate confrontation method, finding that $86.25 \%$ control rate of cucumber gray mold was achieved with strong disease prevention effect shown when microbial fermentation broth had a matching of 5:4:1 by volume and the number of living spores was $1.5 \times 10^{7} \mathrm{cfu} / \mathrm{mL}$. Ji et al. [17] confirmed that the application of compound microbial community reduced the soil nematode propagation index, with control rate of root-knot nematodes reaching 56.5 and $42.5 \%$, respectively.

In recent years, scholars have studied the allelopathic effect of plants and its rhizosphere biological mechanisms, confirming that both positive and negative effects of interactions between plants of the same or different species are a result of the interaction between root exudates-mediated plants and specific microorganisms. Root exudates play an important role in regulating the structure and function of rhizosphere micro-ecological systems, and their interaction with specific microorganisms in the rhizosphere constitutes an important process in allelopathic effect of crops [18-28]. At present, existing researches on compound microbial community in China are concentrated on pot experiments. Whether there is allelopathic effect on cucumber fusarium wilt when compound microbial community is used in Cucumis sativus production, how about the allelopathic effect, how it affect Cucumber growth and biomass production, further research is needed in these regards [17, 39-33].

In this experiment, bio-organic fertilizer was used as Cucumber base fertilizer, compound microbial community was applied to Cucumis sativus in different growth stages at the later stage, and the two were compounded. Through culture of colony diameter of cucumber fusarium wilt, investigation of incidence of field fusarium wilt and recording and determination of vegetative growth traits of Cucumber by laboratory, influence of complex formulation of "WoFengKang" bio-organic fertilizer and compound microbial community on allelopathic effect of cucumber fusarium wilt, field allelopathic control and field growth traits of Cucumis sativus was investigated, which will provide a scientific basis for allelopathic prevention and control of soil-borne diseases and high-efficiency and high-quality cultivation of greenhouse vegetables in the future.

\section{Material and methods}

\subsection{Overview of the test site}

The test site is located in Hongshan District, Chifeng City, Inner Mongolia $\left(118^{\circ} 53^{\prime} \mathrm{E}, 42^{\circ} 13^{\prime} \mathrm{N}\right)$. The soil in this area is clay loam. The annual average temperature is 7 , the annual illumination hour is $3000 \mathrm{~h}$, the frost-free period is $135 \sim 145 \mathrm{~d}$, and the annual average precipitation is $370 \mathrm{~mm}$, and the site is in temperate semi-arid continental monsoon climate zone. The basic chemical properties of the tested soil at $0 \sim 20 \mathrm{~cm}$ were: $\mathrm{pH} 8.39$, conductivity $93.65 \mu \mathrm{S} / \mathrm{cm}$, organic matter $1.34 \%$, nitrate nitrogen $7.28 \mathrm{mg} / \mathrm{kg}$, ammonium nitrogen $0.11 \mathrm{mg} / \mathrm{kg}$, available phosphorus $134.5 \mathrm{mg} / \mathrm{kg}$, and available potassium $106.2 \mathrm{mg} / \mathrm{kg}$.

\subsection{Test materials}

'Jinchun No. 4' Cucumis sativus variety: provided by Tianjin Kerun Cucumber Research Institute; Cucumber fusarium wilt: provided by the Vegetable Cultivation Laboratory of the Agricultural College of Inner Mongolia Agricultural University; "WoFengKang" bio-organic fertilizer: provided by Beijing Qigao Biologics Co., Ltd., total nutrient $\geq 5 \%$, organic matter $\geq 45 \%$, effective viable count $\geq 50$ million/ gram, containing trace elements like calcium, magnesium, sulfur, boron, zinc , molybdenum, copper, iron, net content $40 \mathrm{~kg} / \mathrm{bag}$; "WoFengKang" compound microbial community: provided by Beijing Qigao Biologics Co., Ltd., effective viable count $\geq 5$ billion/ml, water agent, $1000 \mathrm{ml} / \mathrm{bottle}$, effective strains are Bacillus subtilis and Clonostachys rosea;

Conventional control organic fertilizer: provided by Inner Mongolia Liaozhongjing Agricultural Science and Technology Co., Ltd., total nutrient $\geq 5 \%$, organic matter $\geq 45 \%$, humic acid $\geq 15 \%$, amino acid $\geq 1.5 \%$, effective viable count $\geq 200$ million / gram, $\mathrm{CaO} \geq 6 \%, \mathrm{SiO}_{2} \geq 6 \%$, net content $40 \mathrm{~kg} / \mathrm{bag}$; 
Mengduoli Sanan compound fertilizer: provided by Neimenggu Zhongjing Huier Biological Technology Co., Ltd., total nutrient $\geq 54 \%, \mathrm{~N}: \mathrm{P}_{2} \mathrm{O}_{5}: \mathrm{K}_{2} \mathrm{O}=18: 18: 18$, net content $40 \mathrm{~kg} / \mathrm{bag}$;

Rare earth superphosphate fertilizer: provided by Qinhuangdao Tianhao Chemical Co., Ltd., $\mathrm{Ca} \geq 17 \%, \mathrm{~S} \geq 11 \%$, effective phosphorus pentoxide $\geq 12 \%$, rare earth content $0.2 \%-0.3 \%$, net content $40 \mathrm{~kg} / \mathrm{bag}$.

\subsection{Experimental design}

This experiment took the conventional fertilization by farmers in Chifeng area as the control, and used "WoFengKang" bio-organic fertilizer as the base fertilizer which was compounded with "WoFengKang" compound microbial community in later stage. There were 5 treatments, each treatment had 3 repetitions with regular field management. The experiment was completed in the cold shed of the research base of Chifeng University from May to September 2019. "WoFengKang" bioorganic fertilizer was applied in the amount of 3, 6, 9, and 12 bags/mu. The conventional CK was applied according to the local farmers' habit of $9 \mathrm{bags} / \mathrm{mu}$. Cucumis sativus was sowed, followed by seedling raising on May 29, 2019 and planted on July 15. The plant spacing was $35 \mathrm{~cm} \times 55 \mathrm{~cm}$, and the plot area was $5.5 \mathrm{~m}^{2}$. The specific treatment combination and fertilization scheme are shown in Tables 1 and 2.

Table 1. Complex formulation combinations of "WoFengKang" bio-organic fertilizer and compound microbial community

\begin{tabular}{cccccc}
\hline $\begin{array}{c}\text { Different } \\
\text { treatments }\end{array}$ & $\begin{array}{c}\text { "WoFengKang" bio- } \\
\text { organic fertilizer } \\
\text { (kg/mu) }\end{array}$ & $\begin{array}{c}\text { "WoFengKang" } \\
\text { compound microbial } \\
\text { community } \\
\text { (bottle/mu) }\end{array}$ & $\begin{array}{c}\text { Organic } \\
\text { fertilizer } \\
\text { (kg/bag) }\end{array}$ & $\begin{array}{c}\text { Mengduoli Sanan } \\
\text { compound fertilizer } \\
\text { (kg/mu) }\end{array}$ & $\begin{array}{c}\text { Rare earth } \\
\text { superphosphate } \\
\text { fertilizer (kg/mu) }\end{array}$ \\
\hline Treatment 1 & 360 & 2 & 0 & 40 & 40 \\
\hline Treatment 2 & 360 & 4 & 0 & 40 & 40 \\
\hline Treatment 3 & 360 & 6 & 0 & 40 & 40 \\
\hline Treatment 4 & 360 & 8 & 0 & 40 & 40 \\
\hline Conventional CK & 0 & 0 & 360 & 40 & 40 \\
\hline
\end{tabular}

Table 2. Period of use and dosage of "WoFengKang" compound microbial community

\begin{tabular}{ccccccc}
\hline $\begin{array}{c}\text { Different } \\
\text { treatments }\end{array}$ & $\begin{array}{c}\text { Cucumis } \\
\text { sativus } \\
\text { planting period } \\
\text { (times) }\end{array}$ & $\begin{array}{c}\text { Rejuvenation } \\
\text { period (times) }\end{array}$ & $\begin{array}{c}\text { Blossom and } \\
\text { fruit } \\
\text { period(times) }\end{array}$ & $\begin{array}{c}\text { First fruiting } \\
\text { period(times) }\end{array}$ & $\begin{array}{c}\text { Full bearing } \\
\text { period(times) }\end{array}$ & $\begin{array}{c}\text { 7d before } \\
\text { seedling } \\
\text { raising (times) }\end{array}$ \\
\hline Treatment 1 & 1 & 1 & 0 & 0 & 0 & 0 \\
\hline Treatment 2 & 1 & 1 & 1 & 1 & 1 & 0 \\
\hline Treatment 3 & 1 & 1 & 1 & 2 & 2 & 1 \\
\hline Treatment 4 & 1 & 1 & 1 & 0 & 0 & 0 \\
\hline $\begin{array}{c}\text { Conventional } \\
\text { CK }\end{array}$ & 0 & 0 & 0 & & 0 & 0 \\
\hline
\end{tabular}

Note: "WoFengKang" compound microbial community was used from the time of Cucumber planting, with a dosage of 1 bottle/mu/time. The dosages are the same for the following. It was used once in the planting period, once after rejuvenation, once in the blossom and fruit period, 1-2 times in the initial fruiting period, 1-2 times in the full bearing period, and once at $7 \mathrm{~d}$ before seedling raising.

\subsection{Measurement indicators and methods}

\subsubsection{Method to determine colony diameter and allelopathic effect}

Amid seedling raising of the Cucumis sativus (October 20, 2019), the above differently- treated soil samples were taken and the soil at $0 \sim 20 \mathrm{~cm}$ layer of rhizosphere of the Cucumis sativus plants was collected using a soil drill. By "W" type 5-point sampling method, the soil was thoroughly mixed and loaded in plastic bag, sent to the indoor laboratory. Fresh soil samples of different treatments were extracted in the laboratory using ethanol extractant to obtain differently- treated soil leaching liquor. 
Under aseptic conditions, PDA medium was added to the above soil leaching liquor to culture cucumber fusarium wilt in a constant temperature drying oven at $28^{\circ} \mathrm{C}$ and measure the colony diameter and allelopathic effect.

Preparation of soil leaching liquor: Using ethanol as a soil extractant, the extraction was performed according to soil sample mass: extractant volume $=1: 2$. After oscillation extraction for $24 \mathrm{~h}$ on a shaker $\left(25^{\circ} \mathrm{C}, 110 \mathrm{r} / \mathrm{min}\right)$, the soil was filtered through 6 layers of gauze and then filtered through a layer of qualitative filter paper to obtain the soil leaching liquor.

Plate preparation: $2 \mathrm{~mL}$ of the above differently-treated soil leaching liquor was transferred to a 9 $\mathrm{cm}$ diameter Petri dish, then $18 \mathrm{~mL}$ molten PDA medium was added and mixed to prepare a plate. 2 $\mathrm{mL}$ soil leaching liquor was added as treatment, while $2 \mathrm{~mL}$ ethanol extractant plate and $20 \mathrm{~mL}$ PDA medium (blank) plate were added as ethanol CK and total CK, respectively.

Inoculation culture: Under aseptic conditions, a fungus cake was punched with a $0.6 \mathrm{~cm}$-diameter puncher, and transferred to the above different mediums using inoculating needle, with the hyphae downward and one cake per dish, which was placed in the center of the dish. It was then cultured in a $25^{\circ} \mathrm{C}$ constant temperature incubator, and each treatment was repeated 5 times. The colony diameter was determined by crossing method.

Colony diameter $(\mathrm{cm})=$ average value of the measured colony diameter- 0.6 ; Allelopathic effect $(\%)=($ control colony diameter - treated colony diameter $) /$ control colony diameter $\times 100$.

\subsubsection{Field Inoculation and determination of Cucumber fusarium wilt}

During Cucumis sativus seedling raising (October 20, 2019), the above differently-treated soils were loaded to seedling-raising pot for Cucumis sativus planting. Cucumber fusarium wilt (FOC) was inoculated when the rough leaf of Cucumis sativus fully unfolded and incidence of cucumber fusarium wilt was recorded after inoculation for $7 \mathrm{~d}$. Then, measure the disease index and prevention and treatment effects. There were 25 seedling raising pots in each treatment, which were $8 \mathrm{~cm}$ in diameter and filled with soil. Each treatment was repeated 4 times. Cucumis sativus seeds were germinated at a constant temperature $\left(28^{\circ} \mathrm{C}\right)$ illumination incubator. After germination, the seeds were sown in a seedling-raising pot loaded with soil, one seed per hole, which were then routinely managed. When the rough leaf of Cucumis sativus seedlings fully unfolded, a square was cut with a knife at $1 \mathrm{~cm}$ from the root of the Cucumis sativus, and cucumber fusarium wilt was inoculated by root pouring (FOC, $1.0 \times 10^{6}$ in concentration, $5 \mathrm{~mL}$ was poured to the square per pot). The incidence of the disease was investigated after $7 \mathrm{~d}$ of inoculation. Investigation was made once every other day for a total of 6 times. The disease index and control effect were measured. The reference criteria for different grades of cucumber fusarium wilt are as follows [34]:

Grade 0, no symptom;

Grade 1, the hypocotyls and cotyledons are slightly wilted, and the cotyledons lose luster;

Grade 2, plant has mild wilting or there is cotyledon wilting;

Grade 3, the plant is obviously wilted or dwarfed;

Grade 4, the plants are severely wilting or withering.

Disease index $=\Sigma$ (condition level $\times$ number of diseased plants at this level) $/$ (the highest level of disease $\times$ total number of plants $) \times 100 \%$;

Control effect $(\%)=($ control disease index - treated-disease index $) /$ control disease index $\times 100 \%$.

\subsubsection{Recording and determination of Cucumis sativus field growth traits}

After the first female flower of Cucumis sativus showed initial fruit expansion, the initial flowering stage and the fruiting stage, the first female flower node order, the number of female flowers in 1 30 nodes, the leaf color and the fruit color were recorded. Field vegetative growth index of Cucumis sativus was measured in the early and middle stages of fruiting, including Cucumis sativus stem length, stem diameter, the maximum leaf area and the number of leaves. 15 plants were labeled at the three positions (front, middle and back) in each zone under each treatment, and the average of all the 
data was calculated [35-40].

Initial flowering period: also known as budding period or vine growth stage, which is from planting to fruit expansion of first female flower;

Fruiting period: from fruit expansion of the first female flower to seedling raising;

Leaf color: observed in the initial flowering stage and the fruiting stage, generally divided into light green, green and dark green;

Fruit color: observed during maturity, divided into three color uniformity levels of deep, medium and light according to the characteristics of the variety;

Stem length: the highest plant height in whorl stage is measured by a tape measure;

Stem diameter: $1 \mathrm{~cm}$ from the earth surface as measured by a vernier caliper;

Maximum leaf area: select the largest leaf of the plant, measure the length and width with a tape measure, and calculate the product of the two;

Number of leaves: a leaf with a diameter of $\geq 5 \mathrm{~cm}$;

The first female flower node and the number of female flowers within 1 30 nodes of the above labeled plants were recorded.

\subsection{Data processing}

Analysis of variance and data processing were performed using Microsoft Excel 2007 software, SPSS 17.0 software and SAS software [40-42].

\section{Results and discussions}

\subsection{Effects of complex formulation on colony diameter and allelopathic effect of Cucumber fusarium wilt}

The colony diameter of cucumber fusarium wilt cultured by ethanol extract with different complex formulations of compound microbial community and bio-organic fertilizer (Figure 1). Compared with conventional $\mathrm{CK}$, ethanol $\mathrm{CK}$ and total $\mathrm{CK}$, complex formulation of the two results in smaller colony diameter, and as more compound microbial community is used, colony diameter gradually decreases until it no longer changes when the dosage increases to a certain extent. This indicates that the use of compound microbial community has a certain allelopathic effect on cucumber fusarium wilt, and this effect is inhibitory $(P<0.05)$. Where, treatment 3 had the smallest colony diameter of $36.72 \mathrm{~mm}$, which was $43.91 \%, 40.56 \%$ and $53.48 \%$ lower than that of conventional $\mathrm{CK}$, ethanol $\mathrm{CK}$ and total CK, respectively.

Compared with conventional CK, the 4 treatments with compound microbial community show allelopathic effects (Figure 2). Different compound microbial community treatments have obvious allelopathic effects compared with conventional CK $(\mathrm{P}<0.05)$, and conventional CK has allelopathic effect of $27.13 \% \sim 43.91 \%$, indicating that compound microbial community has obvious allelopathic inhibition on cucumber fusarium wilt, and the allelopathic inhibition effect is gradually strengthened with the increase in concentration of compound microbial community, but after a certain concentration is reached, the effect is gradually weakened.

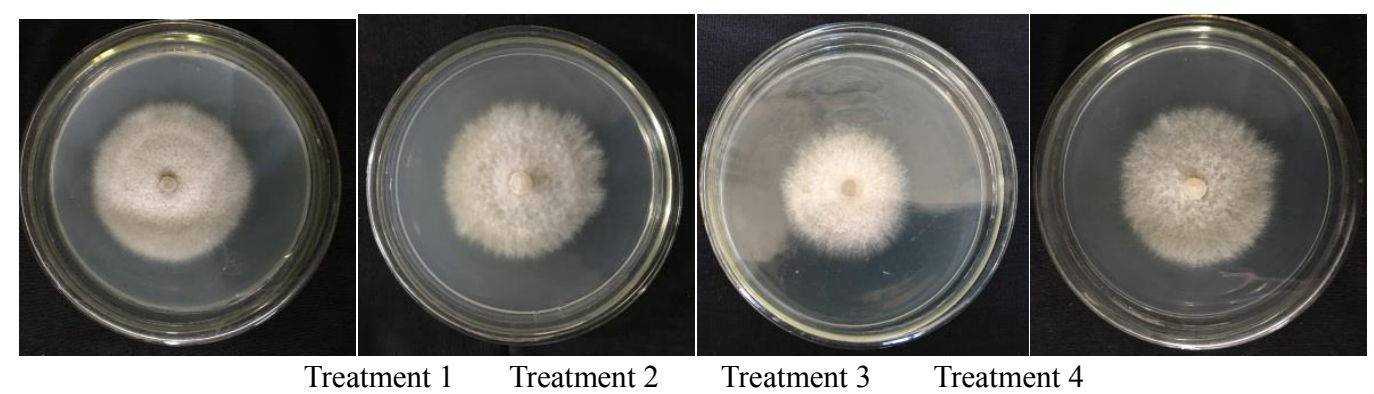




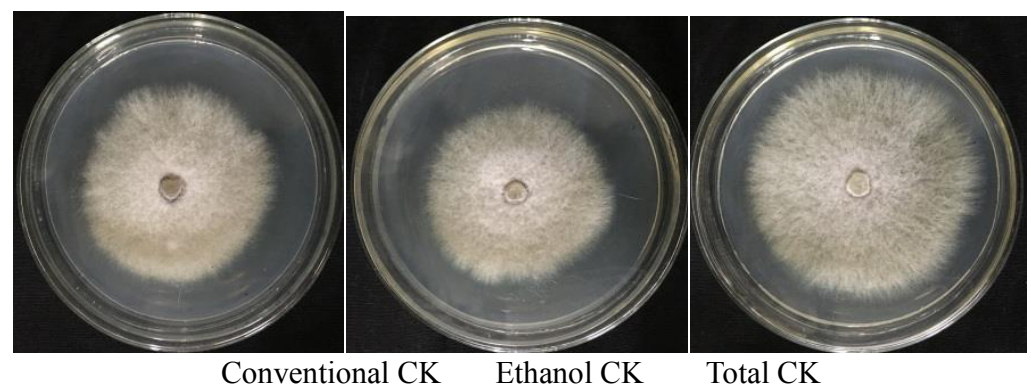

Figure 1. Colony diameter of cucumber fusarium wilt cultured in PDA medium treated with different ethanol extracts at $25^{\circ} \mathrm{C}$ for $144 \mathrm{~h}$

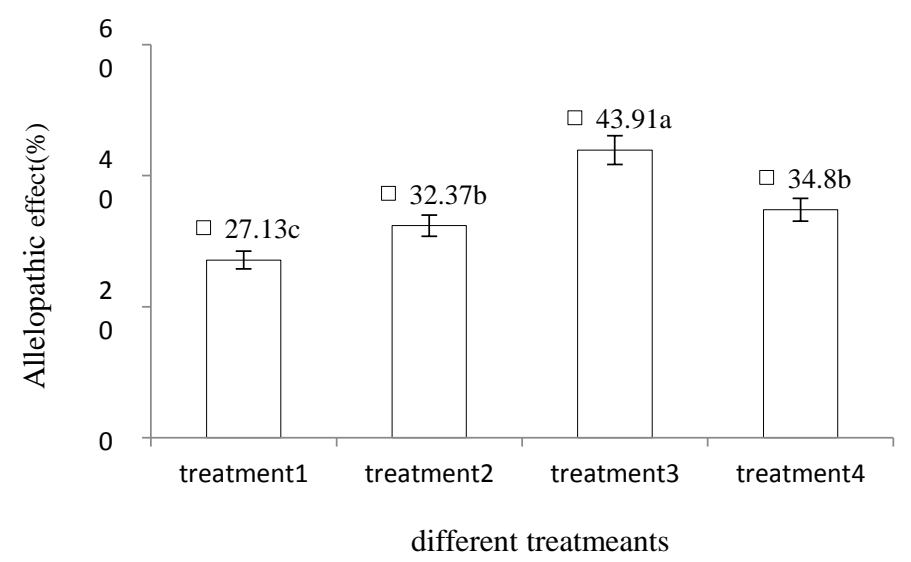

Figure 2. Allelopathic effects of conventional control on Cucumber fusarium wilt in different treatments

\subsection{Control effect of complex formulation on Cucumber fusarium wilt in field and pot experiments}

The soils in different complex formulations were loaded to nutrition pot for Cucumis sativus planting. Cucumber fusarium wilt (FOC) was inoculated using root pouring when the rough leaf of Cucumis sativus fully unfolded and incidence of cucumber fusarium wilt was recorded after inoculation for $7 \mathrm{~d}$. Then, measure the disease index and prevention and treatment effects, with results shown in Table 3. Cucumber fusarium wilt under treatments with compound microbial community has significantly lower disease index than conventional CK $(\mathrm{P}<0.05)$. With the delay of the investigation period, the disease index of each treatment shows an increasing trend, which stabilizes after $13 \mathrm{~d}$ inoculation. The control rate of different treatments reaches $55.94 \sim 72.63 \%$ compared to conventional CK.

Table 3. The incidence and control of cucumber fusarium wilt under different treatments

\begin{tabular}{|c|c|c|c|c|c|c|c|c|c|c|}
\hline \multirow[b]{2}{*}{$\begin{array}{l}\text { Different } \\
\text { treatments }\end{array}$} & \multicolumn{2}{|c|}{$7 \mathrm{~d}$ after inoculation } & \multicolumn{2}{|c|}{$9 \mathrm{~d}$ after inoculation } & \multicolumn{2}{|c|}{$11 \mathrm{~d}$ after inoculation } & \multicolumn{2}{|c|}{$13 \mathrm{~d}$ after inoculation } & \multicolumn{2}{|c|}{$15 \mathrm{~d}$ after inoculation } \\
\hline & $\begin{array}{l}\text { Disease } \\
\text { index }\end{array}$ & $\begin{array}{c}\text { Control } \\
\text { effect } \\
(\%)\end{array}$ & $\begin{array}{l}\text { Disease } \\
\text { index }\end{array}$ & $\begin{array}{c}\text { Control } \\
\text { effect } \\
(\%)\end{array}$ & $\begin{array}{l}\text { Disease } \\
\text { index }\end{array}$ & $\begin{array}{c}\text { Control } \\
\text { effect } \\
(\%)\end{array}$ & $\begin{array}{l}\text { Disease } \\
\text { index }\end{array}$ & $\begin{array}{c}\text { Control } \\
\text { effect } \\
(\%)\end{array}$ & $\begin{array}{l}\text { Disease } \\
\text { index }\end{array}$ & $\begin{array}{c}\text { Control } \\
\text { effect } \\
(\%)\end{array}$ \\
\hline Treatment1 & $17.86 \mathrm{~b}$ & 55.94 & $20.26 \mathrm{~b}$ & 57.12 & $21.27 b$ & 59.48 & $27.17 \mathrm{~b}$ & 60.78 & $28.71 \mathrm{~b}$ & 61.70 \\
\hline Treatment2 & $16.69 b$ & 58.83 & $19.75 b$ & 63.59 & $22.79 b$ & 63.46 & $26.82 b$ & 61.29 & $27.29 b$ & 65.17 \\
\hline Treatment3 & $13.57 \mathrm{c}$ & 66.53 & $16.67 \mathrm{c}$ & 69.27 & $17.59 \mathrm{c}$ & 71.80 & $19.38 \mathrm{c}$ & 72.03 & $19.69 \mathrm{c}$ & 72.63 \\
\hline Treatment4 & $15.41 \mathrm{~b}$ & 61.99 & $18.78 b$ & 65.38 & $19.56 \mathrm{c}$ & 68.64 & $21.49 \mathrm{c}$ & 68.98 & $24.98 b$ & 69.77 \\
\hline $\begin{array}{c}\text { Conventional } \\
\text { CK }\end{array}$ & $40.54 \mathrm{a}$ & & $54.25 \mathrm{a}$ & & $62.37 \mathrm{a}$ & & $69.28 \mathrm{a}$ & & $69.74 a$ & \\
\hline
\end{tabular}

Note: Different lowercase letters indicate significant differences between the same index at the 0.05 level. The same below. 


\subsection{Effect of complex formulation on field growth and development of Cucumis sativus \\ 3.3.1. Effect on the field growth traits of Cucumis Sativus}

Field growth traits of Cucumis sativus under different treatments are shown in Table 4. This table indicates that the initial flowering period of Cucumis sativus treated with compound microbial community was $3.25 \mathrm{~d}$ earlier than that of conventional $\mathrm{CK}$, while the fruiting period is delayed by 4.75d. Cucumis sativus plants have deeper leaf color than conventional CK, the color under compound microbial community is green and dark green, while that of conventional $\mathrm{CK}$ is light green. Cucumis sativus fruit has uniform color that is deeper than that of conventional CK. Significant difference $(P<$ $0.05)$ is achieved between compound microbial community treatment and conventional CK in terms of stem length, stem diameter, maximum leaf area and leaf number, indicating increase by $7.43 \% \sim 20.14 \%, 10.77 \% \sim 52.67 \%, 3.61 \% \sim 42.38 \%$ and $15.83 \% \sim 32.35 \%$, respectively compared with conventional CK. Complex formation of the two can promote early flowering and prolong the fruiting period of Cucumis sativus, which lays a solid foundation for high and stable yield of Cucumis sativus.

Table 4. Survey of field growth traits of Cucumis sativus.

\begin{tabular}{ccccccccc}
\hline $\begin{array}{c}\text { Different } \\
\text { treatment }\end{array}$ & $\begin{array}{c}\text { Initial flowering } \\
\text { period(DD/MM) period(DD/MM) }\end{array}$ & $\begin{array}{c}\text { Fruiting } \\
\text { Leaf color }\end{array}$ & Fruit color & Stem length & $\begin{array}{c}\text { Stem diameter Maximum leaf } \\
(\mathrm{mm})\end{array}$ & $\begin{array}{c}\text { Number of } \\
\text { area }\left(\mathrm{cm}^{2}\right)\end{array}$ \\
\hline leaves
\end{tabular}

\subsubsection{Effect on Cucumis sativus flowering}

Different treatments lower the first female flower node order of Cucumis sativus (Figure 3). This is indicates that complex formation of the two treatments lowers the first female flower node order of Cucumis sativus, and the average node order is 4.19 , which is significantly lower than conventional CK by $11.20 \% \sim 24.56 \%(P<0.05)$. It suggests that the use of compound microbial community and bio-organic fertilizer can lower the first female flower node order of Cucumis sativus and promote early flowering and fruiting of Cucumis sativus.

The effect of different treatments on the number of female flowers per 5 nodes of 1 30 Cucumis sativus nodes is shown in Figure 4, that shows the different treatments increase the number of female flowers per 5 nodes of 1 30 Cucumis sativus nodes. Compared with conventional CK, insignificant difference exists in the number of female flowers per 5 nodes of the first 15 nodes, while there are significant differences in female flower number per 5 nodes after the 15 th node $(P<0.05)$. The number of female flowers in 1 30 nodes of Cucumis sativus treated with different complex formulations increases by $1.73 \sim 3.73$ nodes compared to conventional $\mathrm{CK}$, respectively, with an increase of $14.98 \% \sim 32.29 \%$. The increase in female flower number in 30 Cucumis sativus nodes is favorable to early yield formation of Cucumis sativus, which lays a foundation for achieving higher economic benefits of Cucumis sativus. 


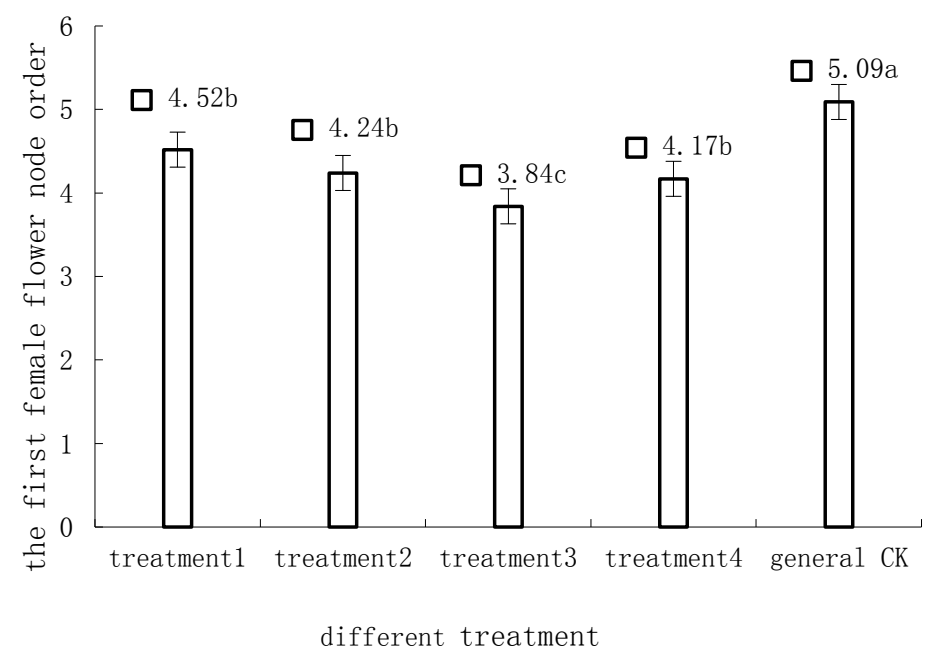

Figure 3. Effect of complex formulation of compound microbial community and bio-organic fertilizer on the first female flower node order of Cucumis sativus

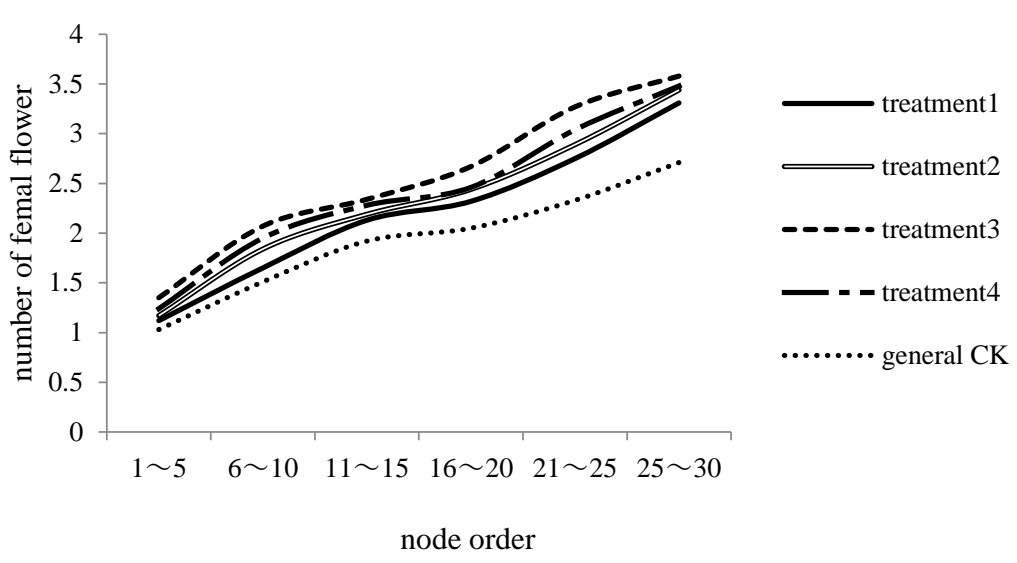

Figure 4. Effect of formulation of compound microbial community and bio-organic fertilizer on the number of female flowers per 5 nodes of 1 30 Cucumis sativus nodes

Colony diameter is often used as an indicator for measuring colony growth of pathogenic colonies. Studies on the allelopathic effects of plants and its soil leaching liquor on pathogenic bacteria have been reported. Liu et al. [43] proved that potassium chloride-treated soil leaching liquor had a significant inhibitory effect on the growth of Fusarium graminearum; Huang et al. [44] found that leaching liquor of Aubergine root has significant promoting effect on the growth of three pathogens of Verticillium dahlia, Sclerotinia sclerotiorum and Botrytis cinerea. The members of Ph.D. thesis group have reported the allelopathic effects of leaching liquor of Rhizosphere zone fresh and rot roots of parsley on cucumber fusarium wilt [45-47]. Qin et al. [34] found that the soil leaching liquor of intercropped parsley and Cucumis sativus had an allelopathic effect on cucumber fusarium wilt, and as the intercrop released more allelopathic matters, the colony reproduction and growth of pathogen in cucumber fusarium wilt would be significantly inhibited. Among the three types of soil leaching liquors, ethanol colony had the smallest diameter. At present, it has been confirmed that allelochemicals isolated from crop root exudates mainly include organic acids and its derivatives [48], esters [49], phenols [50] and sulfides [51]. Moreover, studies have shown that allelopathic inhibition of Brassicaceae and Bassica family plants on bacteria and Rhizoctonia solani in soil mainly concerns the 
three nitrogen-containing compounds secreted by the roots [52]. Gao et al. [53] confirmed that ethanol extract of fresh parsley root can secrete four nitrogen-containing compounds. After complex formulation of the two, what substances are produced in Cucumis sativus rhizosphere? Do these substances have allelopathic effect? What is the role and function of allelochemicals? These remains to be further studied.

Yang et al. [54] found that aqueous leaching liquor of parsley root with a higher concentration has an inhibition rate of 11.05 29.31\% against Fusarium oxysporum. Han [45] confirmed that the highest inhibition rate of parsley against cucumber fusarium wilt was 94.37\%. Qin et al. [34] confirmed that the root exudates of parsley have certain inhibitory effect on cucumber fusarium wilt, and the inhibitory effect was obvious. The maximum inhibition rate against cucumber fusarium wilt was up to $75.90 \%$ with the delay of crop growth period.

At present, there have been researches on controlling plant diseases using microbial community. Zhang et al. [55] irrigated root using microbial community $(1 \mathrm{~kg} / \mathrm{mu})+$ amino acid $(1 \mathrm{~kg} / \mathrm{mu})$ for 5 consecutive times during the whole growth period of bananas, finding that damage of banana wilt was lowered, disease index was lower, which favored normal growth of banana plants. Deng et al. [56] confirmed that the application of functional compound microbial communities and bio-organic fertilizers had a control rate of $68.23 \%$ against root-knot nematode in Radish rhizosphere. Lu et al. [57] found that different ratios of soil conditioner and compound microbial communities reduced the incidence of tobacco bacterial wilt, with the highest disease control rate up to $89.99 \%$. There has been no report on the inhibition of cucumber fusarium wilt by topdressing and drip irrigation of compound microbial community. In this study, the differently-treated soils were loaded to seedling-raising pot for Cucumis sativus planting and cucumber fusarium wilt (FOC) was inoculated by root pouring at the seedling stage. The study found that differently- treated soils showed certain allelopathic inhibition on cucumber fusarium wilt, significantly reducing the field incidence of cucumber fusarium wilt. Chen et al. [58] confirmed that ethanol extract of parsley has a strong inhibitory effect on Foc growth. Gao et al. [59] confirmed that five organic acids can be separated from the ethanol extract of fresh parsley. Where, 4-methoxysalicylic acid belongs to salicylic acid, and the salicylic acid signaling pathway in plants is closely related to disease resistance of plants [60]. Therefore, GC-MS identification of allelochemicals in the soil with complex formulation of the two is the next work to be done.

In order to deal with the current soil acidification, hardening, secondary salinization and frequent soil-borne diseases in China, many biological companies and research institutes have developed and prepared different functional antibiological inoculants which regulate the rhizosphere microbial flora to achieve dominance of beneficial bacteria, so that the purposes of disease control, production and quality increase, soil improvement can be reached. The "WoFengKang" compound microbial community used in this experiment was jointly developed by the Chinese Academy of Agricultural Sciences and Beijing Qigao Biologics Co., Ltd. The effective strains were Bacillus subtilis and Clonostachys rosea. For its mechanism, on the one hand, diseases are suppressed through competition with harmful bacteria for nutrition and living space. Secondly, growth of pathogenic bacteria is inhibited by producing substances such as antibacterial peptides, chitinase and antibiotics, and also, the produced auxins, cytokinins and indole acetic acid can hasten rooting and improve plant disease resistance. Studies have shown that compound microbial community can promote the growth of tomato [61], pepper [62], strawberry [63], amaranth [64], potato [65]. The effect of compound microbial community on Cucumis sativus growth has not been reported. Fu Ruimin [77] reported the application of compound microbial community on melons, finding that microbial agents-treated melons have thicker, larger and greener leaves and more vigorous growth than conventional controls. It is also more evident that compound can affect on some cellular changes [67-77].

\section{Conclusions}

This study shows that: complex formulation of compound microbial communities and bio-organic fertilizers at different concentrations can promote vegetative growth of Cucumis sativus, advance 
flowering and fruiting, lower the first female flower node order, increase the number of female flowers within 30 nodes, thus laying a good foundation for premature and high yield of Cucumis sativus, so that economic benefit is higher. This may be because beneficial bacteria of the compound microbial community produces some plant growth hormone through its physiological metabolic activity, which promotes plant rooting and hastens the growth of plant shoots. However, can these plant growth hormones be produced? What substances are these hormones? Further testing is needed. Studies have confirmed that allelochemicals secreted by plant roots can induce population effects of specific microorganisms in the rhizosphere, causing explosive growth of these microbes and ultimately affecting the growth of target plants [18], which are consistent with the results of this study.

\section{References}

1.RICE, E. L., Allelopathy. 2nd ed. New York: Academic Press., 1984, 1-50.

2.WARDLE, D. A., KARBAN, R., CALLAWAY, R. M., The ecosystem and evolutionary contexts of allelopathy. Trend Ecol. Evolu., 26(12), 2011, 655-662.

3.JIANG, M., ZHU, B., CHEVALLIER, J., \& XIE, R. (2018). Allocating provincial CO2 quotas for the Chinese national carbon program. Australian Journal of Agricultural and Resource Economics, 62(3), 457-479.

4.JIANG, M., ZHU, B., CHEVALLIER, J., XIE, R., Allocating provincial CO2 quotas for the Chinese national carbon program. Aust. J. Agri. Resour. Econ., 62(3), 2018, 457-479.

5.ZHU, B., MA, S., XIE, R., CHEVALLIER, J., WEI, Y. M., Hilbert spectra and empirical mode decomposition: A multiscale event analysis method to detect the impact of economic crises on the European carbon market. Comput. Econ., 52(1), 2018, 105-121.

6.ZHU, B., ZHANG, M., HUANG, L., WANG, P., SU, B., WEI, Y. M., Exploring the effect of carbon trading mechanism on China's green development efficiency: A novel integrated approach. Energy. Econ., 85, 2020, 104601.

7.YU, D., ZHU, H., HAN, W., HOLBURN, D., Dynamic multi agent-based management and load frequency control of PV/Fuel cell/wind turbine/CHP in autonomous microgrid system. Energy, 173, 2019, 554-568.

8.LEI, Z., YANG, J., HUIBIN, H., CHAO, Y., MIN, L., LINTIAN, M., Preparation of soybean oil factory sludge catalyst by plasma and the kinetics of selective catalytic oxidation denitrification reaction. J. clean. Prod., 217, 2019, 317-323.

9.LEI, Z., JIHAO, C., ZHANG, L., HUIBIN, H., YUSU, W., YONGHUI, L., Preparation of soybean oil factory sludge catalyst and its application in selective catalytic oxidation denitration process. $J$. clean. Prod., 225, 2019, 220-226.

10.CAO, L., TU, C., HU, P., LIU, S., Influence of solid particle erosion (SPE) on safety and economy of steam turbines. Appl. Therm. Eng., 150, 2019, 552-563.

11.WANG, Y., CAO, L., HU, P., LI, B., LI, Y., Model establishment and performance evaluation of a modified regenerative system for a $660 \mathrm{mw}$ supercritical unit running at the IPT-setting mode. Energy, 179, 2019, 890-915.

12.WANG, G., WANG, F., SHEN, F., JIANG, T., CHEN, Z., HU, P., Experimental and optical performances of a solar CPV device using a linear Fresnel reflector concentrator. Renewable Energy, 146, 2020, 2351-2361.

13.LEI, Z., GAO, H., CHANG, X., ZHANG, L., WEN, X., WANG, Y., An application of green surfactant synergistically metal supported cordierite catalyst in denitration of Selective Catalytic Oxidation. J. Clean. Prod., 249, 2020, 119307.

14.WANG, P., LI, J. B., BAI, F. W., LIU, D. Y., XU, C., ZHAO, L., WANG, Z. F., Experimental and theoretical evaluation on the thermal performance of a windowed volumetric solar receiver. Energy, 119, 2017, 652-661.

15.ZHU, B., ZHOU, X., LIU, X., WANG, H., HE, K., WANG, P., Exploring the risk spillover effects among China's pilot carbon markets: A regular vine copula-CoES approach. J. Clean. Prod., 242, 
2020, 118455.

16.YANG, J. Y., WANG, Y. N., YANG, F., DONG, J., CUI, G. H., LIU, H. W., CHENG, H. C., ZHANG, H. L., ZHANG, L. P., Prevention and cure of cucumber gray mold by compound microbial fungicide. Agrochemicals, 57(1), 2018, 67-70.

17.JI, Y., WU, Y. P., WANG, Y., WANG, X. Q., LIU, X. Z., LIU, J. B., XIANG, M. C., Control of cucumber root-knot nematode by functional compound microbial community. Chin. J. Biol. Cont., 32(4), 2016, 493-502.

18.LIN, W. X., Plant allelopathy and its rhizosphere biological mechanism. Chinese Ecology Society. Proceedings of the 17th China Agricultural Ecology and Ecological Agriculture Symposium. 2015, 8484.

19.LIU, X., ZHOU, X., ZHU, B., HE, K., WANG, P., Measuring the maturity of carbon market in China: an entropy-based TOPSIS approach. J. clean. Prod., 229(1), 2019, 94-103.

20.ZHU, B., YE, S., JIANG, M., WANG, P., WU, Z., XIE, R., WEI, Y. M., Achieving the carbon intensity target of China: A least squares support vector machine with mixture kernel function approach. Appl. Energy., 233, 2019, 196-207.

21.ZHU, B., SU, B., LI, Y., Input-output and structural decomposition analysis of India's carbon emissions and intensity, 2007/08-2013/14. App. Energ., 230, 2018, 1545-1556.

22.ZHANG, T., WU, X., SHAHEEN, S. M., ZHAO, Q., LIU, X., RINKLEBE, J., REN, H., Ammonium nitrogen recovery from digestate by hydrothermal pretreatment followed by activated hydrochar sorption. Chem. Eng. J., 379, 2020, 122254.

23.GU, F., MA, B., GUO, J., SUMMERS, P. A., HALL, P., Internet of things and Big Data as potential solutions to the problems in waste electrical and electronic equipment management: An exploratory study. Waste. Manage., 68, 2017, 434-448.

24.JI, Q., GUO, J. F., Oil price volatility and oil-related events: An Internet concern study perspective. Appl. Energy., 137, 2015, 256-264.

25.GUO, J., ZHANG, X., GU, F., ZHANG, H., FAN, Y., Does air pollution stimulate electric vehicle sales? Empirical evidence from twenty major cities in China. J. Clean. Prod., 249, 2020, 119372.

26.GU, F., GUO, J., YAO, X., SUMMERS, P. A., WIDIJATMOKO, S. D., HALL, P., An investigation of the current status of recycling spent lithium-ion batteries from consumer electronics in China. J. Clean. Prod., 161, 2017, 765-780.

27.ZENG, H. B., LIU, X. G., WANG, W., XIAO, S. P., New results on stability analysis of systems with time-varying delays using a generalized free-matrix-based inequality. J. Franklin. Inst., 356(13), 2019, 7312-7321.

28..ZENG, H. B., TEO, K. L., HE, Y., WANG, W., Sampled-data-based dissipative control of TS fuzzy systems. App. Math. Model., 65, 2019, 415-427.

29.TIAN, X., SONG, Z., WANG, B., ZHOU, G., (2020). A Theoretical Calculation Method of Influence Radius of Settlement Based on the Slices Method in Tunnel Construction. Math. Problem. Eng., 2020.

30.TIAN, X., SONG, Z., WANG, J., Study on the propagation law of tunnel blasting vibration in stratum and blasting vibration reduction technology. Soil. Dynamic. Earth. Eng., 126, 2019, 105813.

31.YANG, L., CHEN, H., Fault diagnosis of gearbox based on RBF-PF and particle swarm optimization wavelet neural network. Neur. Comput. App., 31(9), 2019, 4463,-4478.

32.CAO, Y., LI, Y., ZHANG, G., JERMSITTIPARSERT, K., NASSERI, M., An efficient terminal voltage control for PEMFC based on an improved version of whale optimization algorithm. Energy Reports, 6, 2020, 530-542.

33.CAO, Y., WANG, Q., CHENG, W., NOJAVAN, S., JERMSITTIPARSERT, K., Risk-constrained optimal operation of fuel cell/photovoltaic/battery/grid hybrid energy system using downside risk constraints method. Int. J. Hydrogen Energy., 2020,

34.QIN, L. J., CAO, J. F., HAN, W. Q., YUN, X. F., Effects of Intercropping of Cucumber and 
Parsley on Cucumber Growth and Fusarium Wilt. Chin. J. Eco-Agri., 26(5), 2018, 684-692.

35.CAO, Y., WANG, Q., FAN, Q., NOJAVAN, S., JERMSITTIPARSERT, K., Risk-constrained stochastic power procurement of storage-based large electricity consumer. J. Energ. Stor., 28, 2020, 101183.

36.LIU, Y. X., YANG, C. N., SUN, Q. D., WU, S. Y., LIN, S. S., CHOU, Y. S., Enhanced embedding capacity for the SMSD-based data-hiding method. Signal Processing: Image Communication, 78, 2019, 216-222.

37.QUAN, Q., HAO, Z., XIFENG, H., JINGCHUN, L., Research on water temperature prediction based on improved support vector regression. Neur. Comput. App., 2020, 1-10.

38.WANG, H., ZHONG, H., BO, G., Existing forms and changes of nitrogen inside of horizontal subsurface constructed wetlands. Environ. Sci. Poll. Res., 25(1), 2018, 771-781.

39.WANG, H., AN, X., ZHANG, Z., Effect of advanced treatment on ammonia nitrogen contained in secondary effluent from wastewater treatment plant. Fresenius. Environ. Bull., 27(4), 2018, 20432050 .

40.LIU, Z., FENG, J., LIU, B., Pricing and service level decisions under a sharing product and consumers' variety-seeking behavior. Sustainability, 11(24), 2019, 6951.

41.WANG, M., ZHANG, D., CHENG, Y., TAN, S. K., Assessing performance of porous pavements and bioretention cells for stormwater management in response to probable climatic changes. $J$. Environ. Manage., 243, 2019, 157-167.

42.LIU, Z., FENG, J., WANG, J., Resource-Constrained Innovation Method for Sustainability: Application of Morphological Analysis and TRIZ Inventive Principles. Sustainability, 12(3), 2020, 917-939.

43.LIU, X. Y., JIN, J. Y., HE, P., LIU, H. L., LI, W. J., Preliminary study on the relation between potassium chloride suppressing corn stalk rot and soil microorganism characteristics. Plant. Nutr. Fertilizer. Sci., 13(2), 2007, 279-285.

44.HUANG, B. L., ZHU, J. X., XU, Y. D., ZHU, H., LU, C. Y., SHEN, M. X., Promotion of eggplant root exudates and extract on mycelia growth of three soil-borne pathogens. Jiangsu. J. Agri. Sci., 21(4), 2005, 301-305.

45.HAN, Y., The study on the allelopathy of extracts of the root and the rhizosphere of parsley on Fusarium oxysporumf.sp. cucumeris. Hohhot: Inner Mongolia Agricultural University, 2007.

46.XIANG, P. Y., HAN, Y., YUN, X. F., The Allelopathy of ethanol extract of the roots and the rhizosphere of parsley on Fusarium oxysporumf.sp. cucumeris. Acta. Agri. Boreali-Sinica., 23(4), 2008, 45-50.

47.CAO, Y., The study on the allelopathy of extracts of the rotten root and the rhizosphere zone rot soil of parsley on Fusarium oxysporumf.sp. cucumeris. Hohhot: Inner Mongolia Agricultural University, 2009.

48.HAO, W. Y., REN, L. X., RAN, W., QI, R. S., Allelopathic effects of root exudates from watermelon and rice plants on Fusarium oxysporum f. sp. niveum. Plant. Soil., 336(1/2), 2010, 485 497.

49.WU, H. S., LIU, Y. D., YANG, X. I., CHEN, X. Q., WANG, Z. H., KONG, X. Y., LIU, X. X., YAN, S., Growth responses of in vitro Fusarium oxysporum f. sp. niveum to external supply of tannic acid. J. Environ. Biol., 31(6), 2010, 1017-1022.

50.SUN, J. B., PENG, M., WANG, Y. G., ZHAO, P. J., XIA, Q. Y., Isolation and characterization of antagonistic bacteria against Fusarium wilt and induction of defense related enzymes in banana. Afr. $J$. Microbiol. Res., 5(5), 2011, 509-515.

51.ZHANG, H., MALLIK, A., ZENG, R. S., Control of panama disease of banana by rotating and intercropping with Chinese chive (Allium tuberosum Rottler): Role of plant volatiles. J. Chem. Ecol., 39(2), 2013, 243-252.

52.MOWLICK, S., YASUKAWA, H., INOUE, T., TOSHIAKI, T., NOBUO, K., KTSUJI, U., 
ATSUKO, U., Suppression of spinach wilt disease by biological soil disinfestation incorporated with Brassica juncea plants in association with changes in soil bacterial communities. Crop. Protect., 54, 2013, 185-193.53.GAO, X. M., WANG, J. G., LI, J., MA, L. G., HAO, J., YUN, X. F., Allelopathic effects of fresh parsley root acetone extracts on Fusarium oxysporumf.sp. cucumeris and allelochemicals identification. Chin. J. Eco-Agri., 22( 11), 2014, 1364-1371.54.YANG, Y. F., YAO, Z. J., LI, B. L., Allelopathic effects of aqueous extract of parsley root on Fusarium Oxysporum f.sp.niveum. Jiangsu. Agri. Sci., 39(6), 2011, 224-225.

55.ZHANG, L., LIU, X. L., LI, T., ZHANG, M. L., LI, X. H., FAN, Y. M., Study on the prevention and control of banana wilt by compound microbial community. Bull. Agri. Sci. Technol., 2, 2017, 5759.

56.DENG, X. H., MIN, Y., JIAO, Z. J., YUAN, W. L., GAN, C. X., CUI, L., DENG, S. Y., Study on the control of radish root knot nematode with functional compound microbial community and bioorganic fertilizers. J. Changjiang Veg., 2, 2017, 76-78.

57.LU, J. J., MA, Z. W., XIE, R. H., LI, S. L., Pot experiment of prevention and cure of tobacco bacterial wilt with soil conditioner and complex microbial agent. Chem. Fertilizer Indu., 5, 2014, 7780 .

58.CHEN, L., LI, L., XIANG, P. Y., YUN, X. F., Allelopathy of parsley volatiles on Fusarium oxysporum f. sp.cucumeris . Chin. J. Ecol., 31(4), 2012, 877-881.

59.GAO, X. M., WANG, J. G., YUN, X. F., BAO, Y. Y., Allelopathic Effects of Fresh Parsley Root Ethanol Extracts on Fusarium oxysporum f.sp.cucumeris and Allelochemicals Identification. Chin. J. Biol. Cont., 33(2), 2017, 281-288.

60.WANG, Z., JIA, C. H., LI, J. Y., HUANG, S. Z., XU, B. Y., JIN, Z. Q., Activation of salicylic acid metabolism and signal transduction can enhance resistance to Fusarium wilt in banana (Musa acuminata L. AAA group, cv. Cavendish). Funct. Integr. Genomic., 15(1), 2015, 47-62.

61.YANG, Y. F., LU, L. M., WANG, Y. Q., SHI, L., Effects of compound microbial community on soil physical and chemical properties and tomato growth. Shanghai. Agri. Sci. Technol., 1, 2018, 8081.

62.MIAO, J. S., Effect of root irrigation of compound microbial community on the growth of pepper in greenhouse cultivation. Vegetables, 3, 2017, 16-18.

63.ZHOU, Y. K., NI, X. H., WANG, H. B., Effects of compound microbial community on the growth and quality of greenhouse strawberry. Anhui. Agri. Sci. Bull., 25(10), 2019, 88-89.

64.CAI, M. X., WANG, Y. T., YE, Y. J., LI, P. P., CAI, J. X., Experimental study on the fertilizer effect of compound microbial community on amaranth. Rural. Econ. Sci., 29(16), 2018, 152-153.

65.LI, J., GAO, X., CHEN, J. Y., ZHANG, S. M., CAO, X., MENG, L. Q., Study on the field application effect of microbial compound microbial community on potato. Modern. Agri., 9, 2019, 2829.

66.FU, R. M., XING, W. H., ZHANG, H., ZHANG, L. Q., CHANG, H. P., CAO, H. L., CHEN, W. L., Development of compound microbial agent and its application in greenhouse melon production. Guangdong. Agri. Sci., 42(2), 2015, 68-71.

67.LIANG, Y., LIN, Q., HUANG, P., WANG, Y., LI, J., ZHANG, L., CAO, J., Rice Bioactive Peptide Binding with TLR4 To Overcome H2O2-Induced Injury in Human Umbilical Vein Endothelial Cells through NF-кB Signaling. J. Agri. Food. Chem., 66(2), 2018, 440-448.

68.WANG, L., LIN, Q., YANG, T., LIANG, Y., NIE, Y., LUO, Y., LUO, F., Oryzanol modifies high fat diet-induced obesity, liver gene expression profile, and inflammation response in mice. J. Agri. Food. Chem., 65(38), 201, 8374-8385.

69.NIE, Y., LUO, F., WANG, L., YANG, T., SHI, L., LI, X., SHEN, J., XU, W., GUO, T., LIN, Q., Anti-hyperlipidemic effect of rice bran polysaccharide and its potential mechanism in high-fat diet mice. Food. Func., 8(11), 2017, 4028-4041.

70.GUO, T., LIN, Q., LI, X., NIE, Y., WANG, L., SHI, L., LUO, F., Octacosanol attenuates inflammation in both RAW264. 7 macrophages and a mouse model of colitis. J. Agri. Food. Chem., 
65(18), 2017, 3647-3658.

71.NIE, Y., LUO, F., LIN, Q., Dietary nutrition and gut microflora: A promising target for treating diseases. Trends. Food. Sci. Technol., 75, 2018, 72-80.

72.LI, W., JIA, M. X., WANG, J. H., LU, J. L., DENG, J., TANG, J. X., LIU, C., Association of MMP9-1562C/T and MMP13-77A/G polymorphisms with non-small cell lung cancer in southern Chinese population. Biomol, 9(3), 2019, 107-119.

73.LOU, Y., SHI, J., GUO, D., QURESHI, A. K., SONG, L., Function of PD-L1 in antitumor immunity of glioma cells. Saudi. J. Boil. Sci., 24(4), 2017, 803-807.

74.LOU, Y., YANG, J., WANG, L., CHEN, X., XIN, X., LIU, Y., The clinical efficacy study of treatment to Chiari malformation type I with syringomyelia under the minimally invasive surgery of resection of Submeningeal cerebellar Tonsillar Herniation and reconstruction of Cisterna magna. Saudi. J. Biol. Sci., 26(8), 2019, 1927-1931.

75.LOU, Y., GUO, D., ZHANG, H., SONG, L., Effectiveness of mesenchymal stems cells cultured by hanging drop vs. conventional culturing on the repair of hypoxic-ischemic-damaged mouse brains, measured by stemness gene expression. Open. Life. Sci., 11(1), 2016, 519-523.

76.REN, Y., JIAO, X., ZHANG, L., Expression level of fibroblast growth factor 5 (FGF5) in the peripheral blood of primary hypertension and its clinical significance. Saudi. J. Biol. Sci., 25(3), 2018, 469-473.

77.CHEN, X., XU, Y., MENG, L., CHEN, X., YUAN, L., CAI, Q., SHI, W., HUANG, G., Nonparametric partial least squares-discriminant analysis model based on sum of ranking difference algorithm for tea grade identification using electronic tongue data identify tea grade using e-tongue data. Sens. Actuators. B. Chem., 2020, 127924.

$\overline{\text { Manuscript received: } 17.03 .2020}$ 